\title{
Okul Yöneticileri ve Öğretmenlere Göre Okulun Anlamlandirılması
}

\author{
DOI: 10.26466/opus.761574
}

*

\begin{abstract}
Abdullah Balıkçı *
* Dr.Öğr. Üyesi, İstanbul Üniversitesi-Cerrahpaşa, Hasan Ali Yücel Eğitim Fakültesi, İstanbul/Türkiye E-Posta: abdullah.balikci@istanbul.edu.tr

ORCID: $\underline{0000-0002-9824-0197}$

\section{Öz}

Okulun amaçlarına ulaşması için okul yöneticileri ve öğretmenlerin okula bakış açıları önem taşımaktadır. Bu araştırmada amaç okul yöneticileri ve öğretmenlerin okulu nasıl bir değer kabul ettiklerini anlamaktır. Araştırma nedensel-karşılaştırmalı araştırma modeliyle yapılmıştır. Araştırmanın örneklemini, tabakalı tesadüfï örnekleme yoluyla seçilen 318 okul yöneticisi ve öğretmen oluşturmaktadır. Araştırmada, 8 boyutlu ve 40 maddeden oluşan örgütsel teşhis ölçeğinden yararlanılmıştır. Verilerin çözümlenmesinde bağımsız $t$ testi ve tek yönlü varyans analizinden (ANOVA) yararlanılmıştır. Ölçeğin güvenirlik katsayısı ,93'dür. Araştırma sonucunda cinsiyet değişkeninde kadınlar lehine insan ilişkileri ve görev değişkeninde öğretmenler lehine tutum boyutunda anlamlı bir fark bulunmuş̧tur. Diğer değişkenlerde ve boyutlarda anlamlı fark bulunamamıştır. Araştırma verileri okula yönelik olarak katılımctların olumlu değerleri benimsediğini ancak her okulda aynı düzeyde ve etkide deneyimlerin yaşanmadığını göstermektedir. Okullarda yaşananlar noktasında olumlu ve olumsuz düşüncelerin okuldan okula değiştiği anlaşılmaktadır. Araştırmacılar açısından şunlar önerilebilir: Daha fazla katılımcıyla mevcut araştırma tekrarlanabilir ve sonuçlar karşılaştırılabilir. Farkl yöntemle konu araştırılabilir. Araştırma sonuçları eğitim politikalarının oluşturulmasında ve geliştirilmesinde dikkate alınabilir. Sonuçlar farklı eğitim ortamlarında paylaşılabilir.
\end{abstract}

Anahtar Kelimeler: okul, okul yöneticisi, öğretmen 


\title{
Making Sense of School According to School Administrators and Teachers
}

\begin{abstract}
School administrators and teachers' point of views towards the school is important for the school to achieve its goals. This research aimed to understand how school administrators and teachers accepted the school. The research was carried out using a causal-comparative research model. The sample group consisted of 318 school administrators and teachers selected using stratified random sampling. In this research, an organizational diagnostic scale consisting of 8 dimensions and 40 items was used. Independent t-test and one-way analysis of variance (ANOVA) were used to analyze the data. The reliability coefficient of the scale was 93. As a result of the research, a significant difference was determined in terms of human relations in favor of women considering the gender variable and attitude in favor of teachers considering the task variable. There was no significant difference considering the other variables and dimensions. The research data showed that the participants adopted positive values for the school, but experiences were not at the same level and effect in each school. It was understood that positive and negative thoughts on school experiences varied from school to school. For researchers, the following can be recommended: the current research can be repeated and the results can be compared with a larger study group. The subject can be investigated by different methods. Research results can be taken into account when establishing and developing educational policies. The results can be shared in different educational environments.
\end{abstract}

Keywords: school, school administrator, teacher 


\section{Giriş}

Okullar eğitim öğretimin belli bir plan dahilinde yapıldığı yerler olarak kabul edilebilir. Okullar aynı zamanda iç ve dış çevresi için sosyal hizmet üreten örgütlerdir. Okulun belirtilen fonksiyonlarını yerine getirmesinde çalışanlarının yadsınamaz bir işlevi söz konusudur. Okulun işgörenleri olan öğretmenlerin okulu nasıl anlamlandırdıkları, çalışanların birbirine karşı tutumu okulun amaçlarına ulaşmasını ciddi bir şekilde etkileyebilmektedir. Öğretmenlerin okulu benimsemesi ve etkin olarak okulda potansiyelini ortaya koymasında çeşitli faktörler etkili olabilmektedir. Bunlar alanyazında takım halinde çalışmanın teşvik edilmesi (Aktan, 2016; Mullen, ve Browne-Ferrigno 2018); okuldaki ortamın, sorumlulukların yerine getirilme düzeyi, karar sürecine katılım (Yavuz-Tabak, 2017); öğrenen bir örgüt olma ve bunun için uygun ortamın hazırlanması (Şen, 2019) gibi faktörlerle açıklanmaktadır. Tüm bu faktörlere dikkat edilerek öğretmeni destekleyici bir tutumun benimsenmesi okula bağllıık, okuldan memnun olma gibi sonuçları da beraberinde getirmektedir (Buehler, Fletcher, Johnston ve Weymouth, 2015).

Öğretmenlerin okula ilişkin tutumları başta olmak üzere okula dair düşüncelerini etkileyen faktörlerden birisi de okul yöneticisiyle etkileşim düzeyleridir. Bu noktada okul yöneticisinden beklenen, okul ve öğretmen arasındaki bağı güçlendirmesi, destekçi bir tutum içine girmesi (Fancera, 2016); okulu olumlu yönde anlamlandırılmasına, yeterliliklerin ve potansiyelin ortaya konmasına yardımcı olması, okula etkide bulunmasıdır (Lee ve Nie, 2016). Belirtilen durumun tersi durumların yaşanması yani öğretmenin performansının kısitlanması, potansiyelinin ortaya onmasının engellenmesi hem mesleki açıdan hem okul açısından hem de okuldaki öğretmenler arası işbirliği açısından ciddi ve olumsuz etkilere neden olabilmektedir (Kılınç, 2014). Okula yönelik yapılan araştırmalarda, okul yöneticisi-öğretmen etkileşimine yönelik araştırmaların olması okul yöneticisinden beklentileri de gündeme getirmektedir. İstenen bir okul ortamı noktasında okul yöneticisinden beklenen insani açıdan değerleri dikkate alması, güvenilirlik, sosyal ve demokratik olma, iş doyumuna katkıda bulunma, motivasyonu artırıcı uygulamalar içinde bulunma, okula bağlılığı sağlama vb. olarak sıralanırken; yöneticilik açısından lider, kararlı, planlı ve işbirlikçi olmasıdır (Akbaşlı ve Diş, 2019; Demirkart, 2015). Benzer bir araştırmaya göre, öğretmenlerin okulla beklentileri üç noktada yoğunlaşmaktadır. Bunlar okul yöneticilerinin kendilerine değer 
vermesi, sinıftaki otoritelerine saygı duyması ve sorumlukların yerine getirme ve istenilen performansın ortaya konulması için yeteri kadar imkân sunmasıdır (Dos Santos, 2020). Öğretmenler okul yöneticisinden bireysel katkı yanında - iyi davranma gibi- mesleki açıdan da katkıda bulunmalarını önemsemektedir. Bireysel ve mesleki açıdan iyi bir iletişimin kurulmasını yaptıkları işten doyum sağlama açısından gerekli görmektedir (Nyenyembe, Maslowski, Nimrod ve Peter, 2016). Ayrıca liderlik ederken etik kaygıların dikkate alınması yöneten-yönetilen iletişim düzeyini etkileyebilmektedir (Kurşun, 2011; Yılmaz, 2006). Tüm bu faktörlerin göz önünde bulundurularak okulun yönetilmesi yani okul yöneticisi ve öğretmen arasında destek, güven, nezaket, mesleki açıdan desteklenme, iletişime açık olmaya özen gösterilmesi okulda güçlü bir kültürün hayata geçirilmesine fırsat sunabilir (Akyol, 2019).

Okula yönelik bakışı etkileyen bir başka husus ise, okulun zaman içinde meydana gelebilecek değişimlere uyum sağalayabilmesidir. Çalık ve Er (2014), okulların değişime ayak uydurabilmesi ve değişimden fayda sağlaması için okulun vizyonuna uygun olarak kararlara katılımı, işbirliğini ve mesleki gelişimi teşvik edici yanının olmasını; Akpınar ve Aydın, (2007), mesleki eğitimlerin alınmasını ön plana çıkarmaktadır. Aksoy ve Özben'e (2019) göre ise, değişimin amacına ulaşması için öğretmen ve yöneticilerin değişime bakış açısı, tutumu ve süreci yönetebilecek yeterliliklere yönelik yapının tesis edilmesi gerekir. Okul yöneticisi ve öğretmenlerin yeterliliklerine yönelik bir yapının inşa edilmesi okulda istenen bir ortama zemin hazırlayabilir. Okulda arzulanan bir ortamın hazırlanmasının önemli bir faydası okulda tükenmişlik sendromunun yaşanmasını asgari düzeye çekebilmesi ya da bu sendromu yok edebilmesidir. Bu şekilde okula karşı tutumun, akademik başarının ve okuldaki motivasyon düzeyinin artmasl; okuldan kopma, okulu benimsememe, iletişimsizlik, iş doyumunun olmaması, demokratik havanın olmaması, kararlara katılımın olmaması gibi olumsuzlukların azalması beklenebilir (Atik, 2016; Bayata, 2017; Durnall, Akbaşlı ve Diş, 2020; Erözyürek, 2019; Kesimal, 2019; Kızıldeniz, 2017; Sezgin, 2006).

Okulu anlamlandırma noktasında belirtilen faktörlerin okuldaki yansımaları farklı sebeplerden dolayı her zaman istenen yönde olamamaktadır. Akkaya'ya (2012) göre, öğrenci ve öğretmenler okulu, kendilerini kıstllayan devamlı kontrol eden, gelişmeyi engelleyici bir sistem olarak algılamaktadır. Benzer bir araştırmaya göre, okula karşı olumlu ancak yapı ve yöneticilere 
karşı nispeten olumsuz algılar söz konusudur (Örücü, 2014). Ertürk'e (2017) göre, problem eğitim sistemi içinde okullarda yaşanan yapısal sorunlardır. Bunlar çevreyle etkili iletişim kurulamaması, performansların adil değerlendirilmemesi, okulun hem yöneten hem yönetilenler için çekici olamaması, istenen gelişim adımlarının atılamaması, öğretmenlerin özlük haklarında yaşanan problemlerdir. Tüm bu yapısal problemler okulun amaçlarına ulaşması noktasında zorluklar oluşturmaktadır. Meral-Şahin'in (2016) yaptığı araştırmaya göre, yönetici ve öğretmenler okulda birlikte karar almayı içeren yönetişim kavramını yeteri kadar hayata geçirememektedir.

Alanyazına bakıldığında okulun önemli bileşenlerinden bir olan öğretmenlerin okulu nasıl anlamlandırdıkları, anlamlandırma düzeyleri ve bunlara etki eden faktörlerin neler olduğu görülebilmektedir. Özellikle okuldan beklentiler, okuldaki yapı, okul yöneticisi etkileşimi ve etkileşim düzeyleri, okuldaki yapının değişimle etkileşimi ve öğretmenlerin performansı ön plana çıkmaktadır. Belirtilen hususlardan hareketle okulun öğretmenlerin ve okul yöneticilerinin perspektifinden araştırılmasının uygun olduğu belirtilebilir. Böylece araştırmanın hem okulu hem öğretmeni anlamaya hem de yapıcı politikaların önünü açmaya yardımcı olacağı düşünülmektedir.

\section{Amaç}

Bu araştırmada amaç, ilköğretim okullarında görev yapan yönetici ve öğretmenlerin okula ilişkin görüşlerini ortaya koymaktır. Bu amaca yönelik olarak şu sorulara cevap aranmıştır:

1. İlköğretim okullarında görev yapan yönetici ve öğretmenlerin okula ilişkin görüşleri cinsiyete göre farklılaşmakta mıdır?

2. İlköğretim okullarında görev yapan yönetici ve öğretmenlerin okula ilişkin görüşleri görev durumuna göre farklılaşmakta mıdır?

3. İlköğretim okullarında görev yapan yönetici ve öğretmenlerin okula ilişkin görüşleri branşa göre farklılaşmakta mıdır?

4. İlköğretim okullarında görev yapan yönetici ve öğretmenlerin okula ilişkin görüşleri kıdeme göre farklılaşmakta mıdır? 


\section{Yöntem}

Bu bölümde araştırmanın yöntemine ilişkin çalışmalara yer verilmiştir.

\section{Araştırma Modeli}

Bu araştırmada, ilköğretim okullarında görev yapan yönetici ve öğretmenlerin okula ilişkin algıları nedensel-karşılaştırmalı araştırma modeliyle ortaya konmaya çalışılmıştır. Bu model değişkenler arasındaki ilişkiye odaklanır ve nedenler hakkında sonuçlara varmakta yararlanılır (Best ve Kahn, 2017).

\section{Evren ve Örneklem}

Araştırmanın evrenini 2017-2018 eğitim-öğretim yılında Konya'da görev yapan okul yöneticisi ve öğretmenler oluşturmaktadır. Araştırmanın örneklemini, tabakalı tesadüfí örnekleme yoluyla seçilen 318 okul yöneticisi ve öğretmen oluşturmaktadır. Christensen, Johnson, Turner'a (2015, s. 167) göre, tabakalı tesadüfi örnekleme, evrenin tabakalar olarak adlandırılan bağımsız gruplara ayrılmasına ve her bir gruptan tesadüfi örneklem seçimine dayalı bir örneklemedir. Araştırma grubuna dağıtılan 333 anket formundan 318 tanesi geri dönmüştür. Bu sayı, Balcı (2004) tarafından tespit edilen bir araştırma sonucunda bir yargıya varılabilmesi için anketlerin \% 80'inin geri dönmesi kuralını karşılamaktadır. Araştırmada dört bağımsız değişkene yer verilmiştir. Bunlar cinsiyet (kadın, erkek), görev (okul yöneticisi, öğretmen), branş (sözel alan, sayısal alan ve beceri alanı) ve kıdem (0-5 yıl, 6-11 yıl, 18-23 yıl ve 24 yıl ve üzeri). Branş değiş̧keninde sınıf öğretmenliği, okul öncesi öğretmenliği, sosyal bilgiler öğretmenliği ve dil öğretmenlikleri sözel branş olarak; matematik, fen ve teknoloji branşları sayısal branş olarak; beden eğitimi, müzik, görsel sanatlar, özel eğitim ve bilişim teknolojisi öğretmenlikleri beceri branşları olarak kategorilendirilmiştir. 
Tablo 1. Cinsiyete göre ankete katılanların dağılımı

\begin{tabular}{lll}
\hline Cinsiyet & $\mathrm{N}$ & $\%$ \\
\hline Erkek & 173 & 54,40 \\
\hline Kadın & 145 & 45,60 \\
\hline TOPLAM & 318 & 100 \\
\hline
\end{tabular}

Tablo 1'e göre, cinsiyete göre; ankete katılan 173 eğitimci (\% 54,60) erkek, 145 eğitimci (\% 45,60) kadındır. Toplam 318 eğitimci (\%100) ankete katılmıştır.

Tablo 2. Kıdeme göre ankete katılanların dă̆ılımı

\begin{tabular}{lll}
\hline Kidem & $\mathrm{N}$ & $\%$ \\
\hline $0-5$ Yll $_{1}$ & 51 & 16 \\
\hline $6-11$ Yll & 70 & 22 \\
\hline $12-17$ Yll $_{1}$ & 101 & 31,80 \\
\hline $18-23$ Yll & 53 & 16,70 \\
\hline 24 Y1l ve yukar1 & 43 & 13,5 \\
\hline TOPLAM & 318 & 100 \\
\hline
\end{tabular}

Tablo 2'ye göre; ankete katılan 51 öğretmen (\% 16) 0-5 yıllık, 70 öğretmen (\% 22) 6-11 yıllık, 101 öğretmen (\% 31,80) 12-17 yıllık, 53 öğretmen (\% 16,70) 18-23 yıllık, 43 öğretmen (\% 13, 5) 24 yıl ve daha yukarı bir kıdeme sahiptir.

Tablo 3. Görev ve branş durumuna göre ankete katılanların dağılımı

\begin{tabular}{llllllllll}
\hline \multicolumn{2}{ll}{ Görev } \\
\multicolumn{2}{l}{ Okul yöneticisi } & \multicolumn{1}{l}{ Öğretmen } & \multicolumn{2}{l}{ Sö̈zel Alan } & \multicolumn{2}{l}{ Sayısal Alan } & \multicolumn{2}{l}{ Beceri Alanı } \\
\hline $\mathrm{N}$ & $\%$ & $\mathrm{~N}$ & $\%$ & $\mathrm{~N}$ & $\%$ & $\mathrm{~N}$ & $\%$ & $\mathrm{~N}$ & $\%$ \\
\hline 44 & 13,8 & 274 & 86,2 & 222 & 69,8 & 54 & 17 & 42 & 13,2 \\
\hline
\end{tabular}

Tablo 3'e göre öğretmen olarak görev yapanların (274 öğretmen, \% 86,2) ve sözel branşta (222 öğretmen, \% 69,8) olan öğretmenlerin ağırlıkta olduğu görülmektedir.

\section{Araştırmada Kullanılan Veri Toplama Aracı}

Araştırma için Keçecioğlu'nun (2001) Örgütsel Teşhiş Ölçeği kullanılmıştır. Ölçek, örgütü (okulu) işgörenlerin (öğretmenlerin) gözünden farklı boyutları dikkate aldığı ve okula yönelik görüşleri kapsamlı bir şekilde sorguladığı için tercih edilmiştir. Ölçeğin, her örgütte dikkate alınabilecek boyutları içerdiği 
düşünülmektedir. Ölçeğin boyutları Tablo 1'de gösterilmiştir. Ölçek iki bölümden oluşmaktadır. Birinci bölümde kişisel bilgiler (cinsiyet, görev, branş ve kıdem) yer almaktadır. İkinci bölüm, 40 maddeden ve 8 boyuttan oluşmaktadır. Her bir boyut beş madde ile ölçülmeye çalışılmıştır. Maddelerin boyutlara dağılımı Tablo 1'de gösterilmiştir.

Tablo 4. Ölçek maddelerinin boyutlara dă̆ılımı

\begin{tabular}{ll}
\hline Boyut & Madde No \\
\hline Ana sorumluluklar & $1,9,17,25,33$ \\
\hline Yapı & $2,10,18,26,34$ \\
\hline İnsan ilişkileri & $3,11,19,27,35$ \\
\hline Güdüleme & $4,12,20,28,36$ \\
\hline Destek & $5,13,21,29,37$ \\
\hline Yönetim liderliği & $6,14,22,30,38$ \\
\hline Değişime karşı tutum & $7,15,23,31,39$ \\
\hline Performans & $8,16,24,32,40$ \\
\hline
\end{tabular}

Tablo 4'e göre öğretmenlerin okulu 8 boyutta anlamlandırdıkları görülmektedir. Bunlar ana sorumluluklar, yapı, insan ilişkileri, güdüleme, destek, yönetim liderliği, değişime karşı tutum ve performanstır. Belirtilen alanyazında bu boyutlara yönelik araştırmalara rastlanmaktadır.

Tablo 5. Örgütsel teşhis ölçeği aralık katsayısına göre gruplandırma

\begin{tabular}{ll}
\hline Puan Aralığı & Okul Algilama Düzeyi \\
\hline $1-1,85$ & Çok düşük \\
\hline $1,86-2,71$ & Az düşük \\
\hline $2,72-3,57$ & Düşük \\
\hline $3,58-4,43$ & Orta \\
\hline $4,44-5,29$ & Az Yüksek \\
\hline $6,30-6,15$ & Yüksek \\
\hline
\end{tabular}

Tablo 5'te ölçeğin gruplandırılmasına ilişkin bilgiler sunulmuştur. Okul yöneticileri ve öğretmenlerin okul algısını ölçmek için likert tipi ölçekten yararlanılmıştır. Ölçekteki her maddenin (Güçlü bir biçimde katılıyorum), (Katılıyorum), (Önemsiz ölçüde katılıyorum), (Nötr), (Önemsiz ölçüde katılmıyorum), (Katılmıyorum) ve (Güçlü bir biçimde katılmıyorum) olarak, 7 derece üzerinden ve verilen sıraya göre, 1,2,3,4,5,6,7 şeklinde sayısal değerlerle değerlendirilmesi istenmiştir. Aritmetik ortalamanın değerlendirme aralığ 
için; (7-1=6) olarak hesaplanan aralık katsayısına göre $(6 / 7=0,85)$ seçenek aralıkları düzenlenmiştir.

Tablo 6. Ölçeğin ve alt boyutlarnnın iç tutarhlığı

\begin{tabular}{lll}
\hline Boyut & Madde Sayısı & Cronbach's Alpha \\
\hline Ana sorumluluklar & 5 &, 919 \\
\hline Yapı & 5 &, 920 \\
\hline İnsan ilişkileri & 5 &, 919 \\
\hline Güdüleme & 5 &, 927 \\
\hline Destek & 5 &, 911 \\
\hline Yönetim liderliği & 5 &, 919 \\
\hline Değişime karşı tutum & 5 &, 922 \\
\hline Performans & 5 &, 927 \\
\hline Toplam & 40 &, 930 \\
\hline
\end{tabular}

Tablo 6'da örgütsel teşhis ölçeği için güvenirlik analizi sonuçları yer almaktadır. Araştırmaya katılan okul yöneticileri ve öğretmenlerin ölçeğe verdiği cevapların genel güvenirlik analizi yapıldığında $\alpha=0,930$ güvenirlik katsayısı elde edilmiştir. Elde edilen bulgular ışığında Örgütsel Teşhis Ölçeği'nin yüksek derecede güvenilirliğe sahip olduğu ortaya çıkmıştır.

\section{Verilerin Toplanması}

Araştırmada Örgütsel Teşhis Ölçeği vasıtasıyla veriler toplanmıştır. Ölçeğin araştırmaya gönüllü katılması beklenen yönetici ve öğretmenlere uygulanmasına gayret gösterilmiştir. Ölçeğin uygulanması için Konya İl Milli Eğitim Müdürlüğünden izin alınmış ve ölçek 2017-2018 eğitim öğretim yılında uygulanmiştır.

\section{Verilerin İstatistiksel Analizi}

Araştırmada elde edilen bulgular bilgisayar ortamına aktarılmış ve SPSS 22.0 ile çözümlenmiştir. Çalışma verileri değerlendirilirken tanımlayıcı istatistiksel metotları (Frekans, Yüzde, Ortalama, Standart Sapma) kullanılmıştır. Bunun yanında katılımcı sayısı araştırma için yeterli sayıya ulaştı̆̆ için parametrik testlerden yararlanılmıştır. Bunlardan bağımsız örnek t-testi iki ilişkisiz grup ortalamaları arasındaki fark yöneliktir ve bu iki grup arasında anlamlı bir fark olup olmadığını ortaya koymak için yararlanılır (Büyüköztürk, 
2008, s. 39). Araştırmada cinsiyet ve görev değişkeni iki ilişkisiz grup olduğu için bağımsız örnek t-testinden yararlanılmıştır. Bunun yanında branş ve k1dem değişkenlerinde ikiden fazla grup olduğu için gruplar arası karşılaştırmalarda tek yönlü varyans analiz (ANOVA) kullanılmıştır. Büyüköztürk'e (2008, s. 39) göre, ikiden fazla grupların parametrik karşılaştırmalarında tek yönlü varyans analizinden (ANOVA) yararlanılabilir. Sonuçlar \% 95 güven aralığında, anlamlılık $\mathrm{p}<0,05$ düzeyinde çift yönlü olarak değerlendirilmiştir.

\section{Bulgular}

Bu bölümde, anket yoluyla toplanan verilerin istatistiksel analizi sonucunda elde edilen bulgular, araştırmanın amaçlarında yer alan sorulara göre açıklanıp yorumlanmıştır.

Tablo 7. Cinsiyet bağımsız değişkenine göre puanların dağılımı

\begin{tabular}{|c|c|c|c|c|c|c|}
\hline Boyut & Cinsiyet & $\mathrm{N}$ & $\overline{\mathrm{x}}$ & ss & $\mathrm{t}$ & $\mathrm{P}$ \\
\hline Ana & Kadın & 145 & 10,4759 & 4,42073 & \multirow{2}{*}{,-- 242} & \multirow{2}{*}{, 182 } \\
\hline Sorumluluklar & Erkek & 173 & 10,5838 & 3,54705 & & \\
\hline \multirow[t]{2}{*}{ Yap1 } & Kadın & 145 & 11,8276 & 3,90040 & \multirow{2}{*}{,-- 299} & \multirow{2}{*}{,952 } \\
\hline & Erkek & 173 & 11,9595 & 3,93901 & & \\
\hline \multirow{2}{*}{$\begin{array}{l}\text { İnsan } \\
\text { İişkileri }\end{array}$} & Kadın & 145 & 11,3931 & 4,24967 & \multirow{2}{*}{$-1,890$} & \multirow{2}{*}{0,05} \\
\hline & Erkek & 173 & 10,5838 & 3,38261 & & \\
\hline \multirow[t]{2}{*}{ Güdüleme } & Kadın & 145 & 14,1034 & 5,26483 & \multirow{2}{*}{$-2,042$} & \multirow{2}{*}{0,010} \\
\hline & Erkek & 173 & 13,0000 & 4,37355 & & \\
\hline \multirow[t]{2}{*}{ Destek } & Kadın & 145 & 12,3862 & 4,59043 & \multirow{2}{*}{,-- 085} & \multirow{2}{*}{,667 } \\
\hline & Erkek & 173 & 12,4277 & 4,16125 & & \\
\hline \multirow{2}{*}{$\begin{array}{l}\text { Yönetim } \\
\text { Liderliği }\end{array}$} & Kadın & 145 & 12,3517 & 5,19686 & \multirow{2}{*}{,- 208} & \multirow{2}{*}{134} \\
\hline & Erkek & 173 & 12,2370 & 4,62883 & & \\
\hline \multirow[t]{2}{*}{ Tutum } & Kadın & 145 & 12,8069 & 4,59815 & \multirow{2}{*}{,- 304} & \multirow{2}{*}{904} \\
\hline & Erkek & 173 & 12,6474 & 4,72099 & & \\
\hline \multirow[t]{2}{*}{ Performans } & Kadın & 145 & 10,5862 & 3,83077 & \multirow{2}{*}{,- 225} & \multirow{2}{*}{071} \\
\hline & Erkek & 173 & 10,4971 & 3,23431 & & \\
\hline
\end{tabular}

Tablo 7'ye göre, cinsiyet durumu bağımsız değişkenine göre, örgütsel teşhis hakkındaki görüşlerin karşılaştırılması bağımsız t-testi (t) ile yapılmıştır. Analiz sonucuna göre insan ilişkileri alt boyutunda istatistiksel olarak anlamli bir farklılık bulunmuştur $(\mathrm{P} \leq 0,05)$. Aritmetik ortalamalara bakıldığında insan ilişkileri alt boyutunda kadınların aritmetik ortalamaları $(11,3931)$ erkeklerin artimetik ortalamalarından $(10,5838)$ daha yüksek çıkmıştır. Bunun yanında ana sorumluluklar, yapı ve destek alt boyutu hariç tüm boyutlarda kadınların erkeklerden daha yüksek puan aldıkları görülmektedir. 
Tablo 8. Görev durumu bağımsız değiş̧kenine göre puanların dă̆ılımı

\begin{tabular}{|c|c|c|c|c|c|c|}
\hline Boyut & Görev & $\mathrm{N}$ & $\bar{x}$ & ss & $\mathrm{t}$ & $\mathrm{P}$ \\
\hline Ana & Okul yöneticisi & 44 & 9,6364 & 3,00458 & & \\
\hline Sorumluluklar & Öğretmen & 274 & 10,6788 & 4,08237 & $--1,624$ & 191 \\
\hline \multirow[t]{2}{*}{ Yap1 } & Okul yöneticisi & 44 & 11,4545 & 3,39257 & \multirow[b]{2}{*}{,-- 811} & \multirow{2}{*}{,316 } \\
\hline & Öğretmen & 274 & 11,9708 & 3,99439 & & \\
\hline \multirow{2}{*}{$\begin{array}{l}\text { İnsan } \\
\text { İlişkileri }\end{array}$} & Okul yöneticisi & 44 & 10,1364 & 2,75842 & \multirow{2}{*}{$-1,532$} & \multirow{2}{*}{,087 } \\
\hline & Öğretmen & 274 & 11,0839 & 3,94981 & & \\
\hline \multirow[t]{2}{*}{ Güdüleme } & Okul yöneticisi & 44 & 11,9773 & 3,93841 & \multirow{2}{*}{$-2,275$} & \multirow{2}{*}{,305 } \\
\hline & Öğretmen & 274 & 13,7482 & 4,91377 & & \\
\hline \multirow[t]{2}{*}{ Destek } & Okul yöneticisi & 44 & 11,4545 & 3,11377 & \multirow{2}{*}{$-1,569$} & \multirow{2}{*}{024} \\
\hline & Öğretmen & 274 & 12,5620 & 4,50862 & & \\
\hline \multirow{2}{*}{$\begin{array}{l}\text { Yönetim } \\
\text { Liderliği }\end{array}$} & Okul yöneticisi & 44 & 11,7045 & 4,79622 & \multirow{2}{*}{,-- 854} & \multirow{2}{*}{ 677 } \\
\hline & Öğretmen & 274 & 12,3832 & 4,90524 & & \\
\hline \multirow[t]{2}{*}{ Tutum } & Okul yöneticisi & 44 & 11,0909 & 2,54100 & \multirow{2}{*}{$-2,520$} & \multirow{2}{*}{, 002} \\
\hline & Öğretmen & 274 & 12,9818 & 4,86706 & & \\
\hline \multirow[t]{2}{*}{ Performans } & Okul yöneticisi & 44 & 9,8182 & 2,69602 & \multirow[b]{2}{*}{$--1,466$} & \multirow[b]{2}{*}{082} \\
\hline & Öğretmen & 274 & 10,6533 & 3,61826 & & \\
\hline
\end{tabular}

Tablo 8'de görev durumu bağımsız değişkenine göre, örgütsel teşhis hakkındaki görüşlerin karşılaştırılması bağımsız t-testi (t) ile yapılmıştır. Boyutlardan elde edilen aritmetik puanlarından sadece tutum boyutunda $(\mathrm{P} \leq 0,05)$ görüşler arasında öğretmenler lehine anlamlı bir fark $(0,02)$ bulunmuştur. Diğer boyutlarda anlamlı bir fark bulunamamasına rağmen puanlara bakıld1ğında ana sorumluluklarda $(10,6788)$, yapıda $(11,9708)$, insan ilişkilerinde (11, 0839), güdülemede $(13,7482)$, destekte $(12,5620)$, yönetim liderliğinde $(12,3832)$, performansta $(10,6533)$ öğretmenler lehine puanların farklılaştığ 1 görülmektedir.

Tablo 9'da branş bağımsız değişkenine göre, örgütsel teşhis hakkındaki görüşlerin karşılaştırılması tek yönlü varyans analizi (ANOVA) ile yapılmıştır. Boyutların hiçbirinde anlamlı bir fark bulunamamıştır. Anlamlı fark bulunamamasına rağmen ortalama puanlarına bakıldığında, sayısal branşta olanların ana sorumluluklar (11, 0185), yapı $(12,4259)$, güdüleme $(13,9074)$, destek $(12,8889)$, yönetim liderliği $(12,5000)$ ve tutum $(13,5556)$ boyutlarındaki puanlarının sözel ve beceri branşında olanların puanlarından daha fazla olduğu görülmektedir. Sözel branşta olanların insan ilişkileri $(11,0270)$ ve performans $(10,6892)$ boyutlarındaki puanlarının sayısal ve beceri branşında olanların puanlarından daha fazla olduğu görülmektedir. 
Tablo 9. Branş bağımsız değişkenine göre puanların dă̆ılımı

\begin{tabular}{|c|c|c|c|c|c|c|}
\hline Boyut & Branş & $\mathrm{N}$ & $\bar{x}$ & SS & $\mathrm{F}$ & $\mathrm{P}$ \\
\hline Ana & Sözel & 222 & 10,4820 & 3,90581 & \multirow{4}{*}{,- 579} & \multirow{4}{*}{,561 } \\
\hline \multirow[t]{3}{*}{ Sorumluluklar } & Sayısal & 54 & 11,0185 & 4,05384 & & \\
\hline & Beceri & 42 & 10,1905 & 4,18614 & & \\
\hline & Total & 318 & 10,5346 & 3,96321 & & \\
\hline \multirow[t]{4}{*}{ Yap1 } & Sözel & 222 & 11,8288 & 3,81441 & \multirow{4}{*}{,- 649} & \multirow{4}{*}{,523 } \\
\hline & Sayısal & 54 & 12,4259 & 4,36367 & & \\
\hline & Beceri & 42 & 11,5952 & 3,87651 & & \\
\hline & Total & 318 & 11,8994 & 3,91583 & & \\
\hline İnsan & Sözel & 222 & 11,0270 & 3,84651 & \multirow{4}{*}{,- 150} & \multirow{4}{*}{,861 } \\
\hline \multirow[t]{3}{*}{ İlişkileri } & Sayısal & 54 & 10,8333 & 3,73029 & & \\
\hline & Beceri & 42 & 10,7143 & 3,85269 & & \\
\hline & Total & 318 & 10,9528 & 3,81773 & & \\
\hline \multirow[t]{4}{*}{ Güdüleme } & Sözel & 222 & 13,5495 & 4,87164 & \multirow{4}{*}{,- 727} & \multirow{4}{*}{,484 } \\
\hline & Sayısal & 54 & 13,9074 & 5,21706 & & \\
\hline & Beceri & 42 & 12,7381 & 4,00036 & & \\
\hline & Total & 318 & 13,5031 & 4,82420 & & \\
\hline \multirow[t]{4}{*}{ Destek } & Sözel & 222 & 12,4550 & 4,28353 & & \multirow{4}{*}{,384 } \\
\hline & Sayısal & 54 & 12,8889 & 4,45382 & 3 & \\
\hline & Beceri & 42 & 11,5476 & 4,58631 & 163 & \\
\hline & Total & 318 & 12,4088 & 4,35523 & & \\
\hline Yönetim & Sözel & 222 & 12,3604 & 4,82320 & \multirow{4}{*}{,- 439} & \multirow{4}{*}{ 645 } \\
\hline \multirow[t]{3}{*}{ Liderliği } & Sayısal & 54 & 12,5000 & 5,46602 & & \\
\hline & Beceri & 42 & 11,6429 & 4,49835 & & \\
\hline & Total & 318 & 12,2893 & 4,88847 & & \\
\hline \multirow[t]{4}{*}{ Tutum } & Sözel & 222 & 12,6171 & 4,40817 & & \multirow{4}{*}{,304 } \\
\hline & Sayısal & 54 & 13,5556 & 5,69563 & & \\
\hline & Beceri & 42 & 12,1905 & 4,45705 & 190 & \\
\hline & Total & 318 & 12,7201 & 4,65873 & & \\
\hline \multirow[t]{4}{*}{ Performans } & Sözel & 222 & 10,6892 & 3,74501 & \multirow{4}{*}{$-1,752$} & \multirow{4}{*}{, 175 } \\
\hline & $\underline{\text { Sayısal }}$ & 54 & 10,6481 & 2,57826 & & \\
\hline & Beceri & 42 & 9,5952 & 3,19343 & & \\
\hline & Total & 318 & 10,5377 & 3,51340 & & \\
\hline
\end{tabular}

Tablo 10'da kıdem bağımsız değişkenine göre, örgütsel teşhis hakkındaki görüşlerin karşılaştırılması tek yönlü varyans analizi (ANOVA) ile yapılmıştır. Boyutların hiçbirinde anlamlı bir fark bulunamamıştır. Ortalama puanlara bakıldığında 6-11 yıl kıdem aralığında olanların ana sorumluluklar (10, 8571), güdüleme (14,1000), yönetim liderliği $(13,0143)$, tutum $(13,0429)$, performans $(10,8429)$ boyutlarındaki puanlarının diğer kıdem gruplarına göre fazla olduğu görülmüştür. 18-23 yıl kıdem aralığında olanların ise yapı (12, $4340)$, insan ilişkileri $(11,4151)$ ve destek $(12,7170)$ boyutlarındaki puanlarının diğer kıdem gruplarına göre fazla olduğu görülmüştür. 
Tablo 10. Kıdem bağımsız değişkenine göre puanların dağılımı

\begin{tabular}{|c|c|c|c|c|c|c|}
\hline Boyut & Kıdem & $\mathrm{N}$ & $\overline{\mathrm{x}}$ & ss & $\mathrm{F}$ & $\mathrm{P}$ \\
\hline Ana & $0-5 Y_{1}$ & 51 & 10,4902 & 3,42562 & \multirow{6}{*}{,- 592} & \multirow{6}{*}{ 668 } \\
\hline \multirow[t]{5}{*}{ Sorumluluklar } & 6-11 Yil & 70 & 10,8571 & 3,93161 & & \\
\hline & 12-17 Yil & 101 & 10,6535 & 3,84821 & & \\
\hline & $18-23 Y_{11}$ & 53 & 10,5849 & 5,17179 & & \\
\hline & 24 Yll ve Üzeri & 43 & 9,7209 & 3,14965 & & \\
\hline & Total & 318 & 10,5346 & 3,96321 & & \\
\hline \multirow[t]{6}{*}{ Yapı } & $0-5$ Yil & 51 & 11,9804 & 3,33161 & \multirow{6}{*}{,- 590} & \multirow{6}{*}{ 670 } \\
\hline & 6-11 Yll & 70 & 12,1286 & 3,94131 & & \\
\hline & $12-17 Y_{11}$ & 101 & 11,6139 & 3,68502 & & \\
\hline & 18-23 Y1l & 53 & 12,4340 & 5,02497 & & \\
\hline & 24 Yll ve Üzeri & 43 & 11,4419 & 3,54093 & & \\
\hline & Total & 318 & 11,8994 & 3,91583 & & \\
\hline İnsan & $0-5$ Yil & 51 & 10,9020 & 3,55671 & \multirow{6}{*}{,- 874} & \multirow{6}{*}{480} \\
\hline \multirow[t]{5}{*}{ İlişkileri } & 6-11 Yll & 70 & 11,2429 & 3,89513 & & \\
\hline & $12-17 Y_{11}$ & 101 & 10,9109 & 3,44992 & & \\
\hline & $18-23 Y_{11}$ & 53 & 11,4151 & 5,07420 & & \\
\hline & $24 Y_{1} l$ ve Üzeri & 43 & 10,0698 & 2,93091 & & \\
\hline & Total & 318 & 10,9528 & 3,81773 & & \\
\hline \multirow[t]{6}{*}{ Güdüleme } & $0-5 Y_{1}$ & 51 & 13,0196 & 4,43392 & \multirow{6}{*}{,- 762} & \multirow{6}{*}{, 550} \\
\hline & 6-11 Yil & 70 & 14,1000 & 4,85485 & & \\
\hline & 12-17 Yil & 101 & 13,3564 & 4,50019 & & \\
\hline & $18-23 Y_{11}$ & 53 & 14,0000 & 5,69413 & & \\
\hline & 24 Yll ve Üzeri & 43 & 12,8372 & 4,84488 & & \\
\hline & Total & 318 & 13,5031 & 4,82420 & & \\
\hline \multirow[t]{6}{*}{ Destek } & $0-5 Y_{11}$ & 51 & 12,0392 & 3,87278 & \multirow{6}{*}{,- 199} & \multirow{6}{*}{,939 } \\
\hline & 6-11 Yil & 70 & 12,5857 & 4,33554 & & \\
\hline & $12-17 Y_{11}$ & 101 & 12,3069 & 3,99686 & & \\
\hline & 18-23 Yil & 53 & 12,7170 & 5,36863 & & \\
\hline & 24 Yll ve Üzeri & 43 & 12,4186 & 4,51048 & & \\
\hline & Total & 318 & 12,4088 & 4,35523 & & \\
\hline Yönetim & $0-5 Y_{11}$ & 51 & 11,5294 & 3,44298 & \multirow{6}{*}{,- 789} & \multirow{6}{*}{, 533} \\
\hline \multirow[t]{5}{*}{ Liderliği } & 6-11 Yll & 70 & 13,0143 & 5,65555 & & \\
\hline & $12-17 Y_{11}$ & 101 & 12,0495 & 4,01591 & & \\
\hline & $18-23 Y_{11}$ & 53 & 12,5472 & 6,49131 & & \\
\hline & 24 Yll ve Üzeri & 43 & 12,2558 & 4,61928 & & \\
\hline & Total & 318 & 12,2893 & 4,88847 & & \\
\hline \multirow[t]{6}{*}{ Tutum } & $0-5 Y_{1}$ & 51 & 12,3725 & 4,21408 & \multirow{6}{*}{,- 167} & \multirow{6}{*}{,955 } \\
\hline & 6-11 Yil & 70 & 13,0429 & 4,01604 & & \\
\hline & 12-17 Yil & 101 & 12,6238 & 3,93154 & & \\
\hline & $18-23 Y_{11}$ & 53 & 12,7925 & 5,81562 & & \\
\hline & 24 Yll ve Üzeri & 43 & 12,7442 & 6,09486 & & \\
\hline & Total & 318 & 12,7201 & 4,65873 & & \\
\hline Performans & $0-5$ Yil & 51 & 10,8235 & 3,93297 & & \\
\hline & 6-11 Yil & 70 & 10,8429 & 3,27766 & & \\
\hline & 12-17 Yil & 101 & 10,3663 & 3,33983 & & \\
\hline & 18-23 Yil & 53 & 10,3774 & 3,88897 & 349 & , 744 \\
\hline & 24 Yll ve Üzeri & 43 & 10,3023 & 3,37734 & & \\
\hline & Total & 318 & 10,5377 & 3,51340 & & \\
\hline
\end{tabular}




\section{Sonuç ve Tartışma}

Yapılan araştırmada öğretmenlerin okula karşı olumlu düşüncelerinin olduğu; ancak bölgeden bölgeye, okuldan okula bu düşüncelerin düzeyinde farklılıklar olduğu anlaşılmaktadır. Bunun yanında şu sonuçlara ulaşılmıştır: Cinsiyet bağımsız değişkene göre, sadece insan ilişkileri boyutunda anlamlı bir fark bulunmuştur. Diğer boyutlarda anlamlı bir fark bulunamamıştır. Ana sorumluluklar, yapı ve destek boyutlarında erkekler lehine puanların farklılaştığı görülürken; insan ilişkileri, güdüleme, yönetim liderliği, tutum ve performans boyutlarında kadınlar lehine puanların farklılaştığı görülmektedir. Kadınların lehine farklılaşmanın ve puanların farklı olması Doğan'ın (2008) yaptı̆̆ı ve kadınların adalet, saygı, insan hakları, güven, örgütsel bağlılık gibi değerleri daha çok önemsediklerini gösteren araştırma sonucuyla; Peker, İnandı ve Kılıç'ın (2018) yaptığı, okul yöneticisi öğretmen etkileşiminde sosyo-kültürel yapıdan kaynaklı olarak kadın öğretmenler okul yöneticileriyle etkileşimlerinde kendilerini erkek meslektaşlarına göre daha az baskı altında hissettiğine yönelik araştırma sonucuyla açıklanabilir. Bunun yanında Yıldırım'ın (2013) yaptığı araştırmada, kadın yöneticilerin erkek yöneticilere göre mentörlük rollerini daha fazla algıladığını ortaya koymaktadır. Bayata'nın (2007) yaptığı araştırmaya göre, kadınların erkeklere göre insani değerlerin okulda daha fazla hissedildiğini düşünmektedir. Demirkart'a (2016) göre, kadınların erkeklere göre örgütsel sosyalleşmenin motivasyon ve bağlılık boyutları puanları erkeklere göre daha fazladır. Erözyürek (2019) ise, kadınların yönetimi demokratik bulma düzeylerinin erkeklere göre daha yüksek olduğunu ortaya koymaktadır. Tüm bu araştırmaların araştırmanın cinsiyet değişkenine yönelik sonucu desteklediği düşünülmektedir. Ancak okul algısı bakımından cinsiyet bağımsız değişkenine göre anlamlı bir fark olmayan ve erkerkelerin puanlarının kadınlara göre yüksek olduğu araştırma sonuçları mevcut araştırma sonucuyla örtüşmediği söylenebilir (Kesimal, 2019; Sezgin, 2006; Şen, 2019; Yavuz-Tabak, 2017).

Görev durumu bağımsız değişkenine göre, sadece tutum boyutunda anlamlı bir fark bulunmuştur. Diğer boyutlarda anlamlı bir fark bulunamamıştır. Puanların tümünün öğretmenler lehine farklılaştı̆̆1 görülmektedir. Alanyazına bakıldığında Olsen ve Huang'ın (2018) yaptığı araştırma, öğretmenler arası işbirliği ve okul müdürünün desteği öğretmenin kurumdaki varlığı ve 
iş doyumu açısından için temel unsurlar olduğunu ve bu iki unsurun öğretmenlerin profesyonel bir ortamda bulunmaları için gerekli olduğunu ortaya koymaktadır. Acharya (2019), öğretmenlerin okuldaki görevlerini yerine getirmesinde gelişimlerinin dikkate alınması gerektiğini vurgulamaktadır. Öğretmenlerin gelişimine yönelik çalışmalar olduğu sürece, okula katkısı ve gelişimi ve algısı da pozitif yönde etkilenecektir. Kılınç'ın (2010) yaptığı araştırma ise, okul yöneticilerinin davranışlarının öğretmenlerce yeterince insani bulunmadığını ve bu durumun görevlerini yapmalarını zorlaştırdığını, cesaretlerini kırdığını, çalışma ortamında zorluklar çıkardığını, başarıyı ulaşmada işlerini zorlaştırdığını ortaya koymaktadır. Şen'in (2019) yaptığı araştırmada görev değişkenine göre, öğrenen okul bağlamında paylaşılan vizyon, kişisel hakimiyet ve zihni modeller açısından anlamlı fark bulunurken; takım halinde öğrenme açısından anlamlı bir fark bulunamamıştır. Belirtilen araştırmaların öğretmenler lehine puanların farklılaşmasını açıkladığı için araştırmayla paralel olduğu; ancak Yavuz-Tabak'ın (2017) yaptığı ve okul müdürlerinin müdür yardımcısı ve öğretmenlere göre demokratik okul kültürne daha fazla olumlu baktığını gösteren araştırmasıyla paralellik göstermediği anlaşılmaktadır.

Branş bağımsız değişkenine göre, hiçbir boyutta anlamlı bir fark bulunamamıştır. Ana sorumluluklar, yapı, destek, güdüleme, yönetim liderliği, tutum boyutlarında puanların sayısal branşlar lehine farklılaştığı görülürken; insan ilişkileri ve performans boyutlarında sözel branşlar lehine farklılaşmanın olduğu görülmektedir. Alanyazına bakıldığında Hilton, Hilton, Dole ve Goos (2015), okul yöneticileri ve öğretmenlerin mesleki gelişim çabası içinde bulunmasının hem yeni bilgi ve becerilerin edinilmesi açısından mesleki gelişime hem de okul yöneticisi öğretmen iletişimine katkı sunacağını ortaya koymaktadır. Wake ve Mills (2018), öğretmenlerin okuldaki çalışmalarında profesyonel açıdan gelişim göstermeleri için desteklenmeleri gerektiğini vurgulamaktadır. Bu destek hem kendilerine hem de öğrenci başarısına dolayısıyla okula olumlu dönüt sağlayacaktır. Benzer bir araştırmaya göre Tsujino (2016), öğretmenin okuldaki performansı noktasında öğrenci, bürokrasi ve profesyonelleşme arasındaki ilişki ve kurulacak yapı ve bunlar arasındaki dengenin okula katkı sunacağını ifade etmektedir. Demirkart (2016) yaptığı araştırmada, sınıf öğretmenlerinin örgütsel sosyalleşme puanlarının diğer branşlara göre daha yüksek olduğunu ortaya koymaktadır. Sezgin (2006) ve 
Şen'in (2019) yaptığı araştırmalarda branş bağımsız değişkenine göre, öğretmenlerin bireysel ve örgütsel değerlere uyumunda anlamlı bir fark yoktur. Belirtilen araştırmaların branş bağımsız değişkeni açısından mevcut araştırma sonucuyla uyumlu olduğu düşünülmektedir.

Kıdem bağımsız değişkenine göre, hiçbir boyutta anlamlı bir fark bulunamamıştır. Ana sorumluluklar, güdüleme, yönetim liderliği, tutum ve performans boyutlarında puanların 6-11 yıl kıdem aralığına sahip olanların lehine farklılaştığı görülürken; yapı, destek, insan ilişkileri boyutunda ise 18-23 yıl kıdem aralığına sahip olanların lehine farklılaşmanın olduğu görülmektedir. Bayata'nın (2007) yaptığı araştırmaya göre, öğretmenlerin demokratik tutum açısından farklı puanlar olmasına rağmen katılım, özgürlük gibi noktalarda öğretmenler benzer düşüncelere sahiptir. Benzer bir araştırma sonucu Erözyürek' in (2019) araştırmasında elde edilmiş ve demokratik okul açısından öğretmenlerin benzer algılara sahip olduğu ortaya çıkmıştır. Kesimal'ın (2019) yaptığı araştırmada ise, öğretmenlerin kıdem açısından öz yeterlik algılarında anlamlı bir fark bulunamamıştır. Bayata (2007), Erözyürek (2019) ve Kesimal'in (2019) araştırmalarının mevcut araştırma sonucunu desteklediği söylenebilir. Bunun yanında Demirkart'ın (2016) yaptığı ve 6-10 yıllık öğretmenler kendilerini daha kıdemlilere göre işe daha az bağlı olduğu; 10-18 yıllık yöneticilerin bu boyuttaki puanının diğer kıdem gruplarında olan yöneticilere göre daha yüksek olduğunu gösteren araştırmasıyla; Sezgin'in (2006), kıdem değişkeni açısından öğretmenlerin bireysel ve örgütsel değerlere uyumunda anlamlı bir fark olduğunu ve birey-örgüt değer uyumu 11-15 yıllık öğretmenlerde diğerlerine göre daha fazla olduğuna işaret eden araştırmasıyla; Şen'in (2019), branş değişkenine göre anlamlı fark 7 yıl ve üzeri öğretmenler lehine bulunan araştırma sonucuyla örtüşmediği belirtilebilir.

Yapılan araştırmadan hareketle araştırmacılar için şunlar önerilebilir: Okul yöneticisi ve öğretmenlerin okul hakkındaki görüşleri örneklem sayısı artırılarak daha ayrıntılı bir şekilde ortaya konabilir. Araştırma konusu farklı yöntemlerle araştırılabilir. Böylece araştırmalardan hareketle karşılaştırmalar yapılabilir. Uygulamacılar için şunlar önerilebilir: Araştırma sonuçları, okula ilişkin oluşturulacak politikalarda dikkate alınabilir. Örgütle ilgili düzenlemelerde araştırma sonucu öğretmenlerin görüşü olarak kabul edilerek düzenlemeler yapılabilir, eğitim politikalarına yön verilebilir. 


\title{
EXTENDED ABSTRACT
}

\section{Making Sense of School According to School Administrators and Teachers}

\author{
Abdullah Balıkçı \\ İstanbul Üniversitesi-Cerrahpaşa
}

Schools can be considered as places where education takes place within a certain plan. Schools are also organizations that produce social services for their internal and external environment. The employees have an undeniable function in fulfilling the specified functions of the school. How teachers, the employees of the school, make sense of the school and the attitude of the employees towards each other can seriously affect the achievement of the goals of the school. Various factors can be effective in the adoption of the school and to reveal its potential in the school effectively. Considering the literature, it can be seen there are studies conducted on how the teachers- one of the important components of the school- make sense of the school, their level of meaning, and the factors affecting them. Especially the expectations from the school, the structure in the school, the interaction and interaction levels of the school administrator, the interaction of the structure in the school with the change, and the performance of the teachers come to the fore. It can be stated that it is appropriate to investigate the school from the perspective of teachers based on the above-mentioned subjects. Thus, it is thought that this research will help to understand both the school and the teacher and to open the way for constructive policies.

This research aimed to reveal the perceptions of the administrators and teachers working in primary schools about the school. In this study, the perceptions of administrators and teachers working in primary schools about the school were attempted to be revealed by using a causal-comparative research model. The universe consisted of school administrators and teachers working in Konya, Turkey, in the 2017-2018 academic year. The sample group consisted of 318 school administrators and teachers selected using stratified random sampling. This research included four independent variables. These were gender (female, male), task (school manager, teacher), branch (verbal field, numerical field and skill field), and seniority (0-5 years, 6-11 years, 18- 
23 years, and 24 years and above). Organizational Diagnosis Scale of Keçecioğlu (2001) was used in this research. A Likert-type scale was used to measure the school perception of school administrators and teachers. This scale was chosen because the organization (school) considered different dimensions from the eyes of the teachers and comprehensively questioned their views on the school. It was considered that this scale included dimensions that could be taken into account in every organization. The dimensions in this scale were the main responsibilities, structure, human relations, motivation, support, administration leadership, attitude towards change, and performance. When the general reliability analysis of the responses of the school administrators and teachers participating in the research was completed, $\alpha=$ 0.930 reliability coefficient was obtained. In light of the findings, it was revealed that the Organizational Diagnosis Scale has a high degree of reliability. The findings obtained were transferred to the computer environment and analyzed using SPSS 22.0 software. Descriptive statistical methods (Frequency, Percentage, Average, Standard Deviation) were used when evaluating the data. In addition, parametric tests were used since the number of participants reached a sufficient number for the research. Results were evaluated bilaterally at a 95\% confidence interval and significance at $\mathrm{p}<0.05$ level. In the research conducted, the following results were obtained: Considering the gender independent variable, only a significant difference was found in the human relations dimension. There was no significant difference considering the other dimensions. While the main responsibilities, structure, and support dimensions differed in favor of male participants, it was seen that the scores differed in favor of female participants considering human relations, motivation, management leadership, attitude, and performance dimensions. According to the task status independent variable, only a significant difference was found in the attitude dimension. There was no significant difference considering the other dimensions. It was seen that all of the scores differed in favor of teachers. According to the branch independent variable, there was no significant difference in any dimension. While it was seen that the scores in main responsibilities, structure, support, motivation, management leadership and attitude dimensions differed in favor of the numerical branches, it was determined that there was a difference in human relations and performance dimensions in favor of verbal branches. There was no significant difference considering in any dimension considering the seniority argument. 
While the main responsibilities, motivation, management leadership, attitude, and performance dimensions differed in favor of those with 6-11 years of seniority, it was seen that there was a differentiation in favor of those with 18-23 years of seniority considering structure, support, and human relations dimensions. Based on the research conducted, the following can be recommended for the researchers: The views of the school administrators and teachers on the school can be revealed in more detail by increasing the sample size. The subject of the research can be researched using different methods. Thus, comparisons can be made based on research. For practitioners, the following can be recommended: The results of the research can be taken into account in the policies to be established regarding the school. In organizational arrangements, arrangements can be made by accepting the opinion of teachers in line with the results of the research, and educational policies can be directed accordingly.

\section{Kaynakça / References}

Acharya, M. (2019). Professional development activities for activity-based learning: case of high school health and population teachers in Kathmandu, Nepal. Research in Pedagogy, 9(2), 143-150. doi: 10.17810/2015.97

Akbaşlı, S., ve Diş, O. (2019). Öğretmen görüşleri doğrultusunda lider okul yöneticilerinin yeterlilikleri. Uluslararası Liderlik Çalı̧maları Dergisi: Kuram ve Uygulama, 2(2), 86-102.

Akkaya, E. (2012). Ortaöğretim öğrenci ve öğretmenlerinin okul ve ideal okul algllarmın metafor yoluyla analizi. Yayımlanmamış Yüksek Lisans Tezi, Gazi Üniversitesi, Ankara.

Akpınar, B., ve Aydın, K. (2007). Eğitimde değişim ve öğretmenlerin değişim alg1ları. Eğitim ve Bilim, 32(144), 71-80.

Aksoy-Özben, Ç. (2019). Okul yöneticilerinin değişimi yönetme yeterlilikleri. Yayımlanmamış Yüksek Lisans Tezi. Kırıkkale Üniversitesi, Kırıkkale.

Aktan, M. C. (2016). Türkiye'de okul sosyal hizmetinin yapılandırlmasina ilişkin nitel bir araştırma: sorunlar, gereksinimler ve çözüm önerileri.Yayımlanmamış Yüksek Lisans Tezi, Hacettepe Üniversitesi, Ankara.

Akyol, Z. (2019). Okul yöneticilerinin demokratik okul anlayışına ilişkin öğretmen görüşleri. Yayımlanmamış Yüksek Lisans Tezi, Marmara Üniversitesi, İstanbul. 
Atik, S. (2016). Akademik başarıların yordayıcıları olarak öğretmene güven, okula karşı tutum, okula yabancılaşma ve okul tükenmişliği. Yayımlanmamış Doktora Tezi, İnönü Üniversitesi, Malatya.

Balc1, A. (2004). Sosyal bilimlerde araştırma. Ankara: Pegem Akademi Yayıncılık.

Bayata, G. (2017). Öğretmen görüşlerine göre okul müdürlerinin demokratik tutumları ile öğretmenlerin örgütsel bağhllı düzeyleri arasındaki ilişkinin incelenmesi. Yayımlanmamış Yüksek Lisans Tezi, Atatürk Üniversitesi, Erzurum.

Best, J. W., ve Kahn, J. V. (2017). Betimsel çalışmalar (M. Çetin, Çev.), (O. Köksal, Çev. Ed.). Eğitimde araştırma yöntemleri (s. 137-176) içinde. Konya: Eğitim.

Buehler, C., Fletcher, A. C., Johnston, C., ve Weymouth, B. B. (2015). Perceptions of school experiences during the first semester of middle school. School Community Journal, 25(2), 55-83.

Büyüköztürk, Ş. (2008). Sosyal bilimler için veri analizi el kitabı (8. Baskı). Ankara: Pegem Yayıncilik.

Christensen, L. B., Johnson, R. B., ve Turner, L. A. (2015). Araştırma yöntemleri desen ve analiz (M. Sever, Z. Avc1-Yurtseven, Çev.), (A. Aypay, Çev. Ed.). Nitel ve karma yöntem araştırmaları (s. 149-180) içinde. Ankara: Anı.

Çalık, T., ve Er, E. (2014). İlköğretim okulu öğretmenlerinin okulun değişime açıklığı ile değişim kapasitesi algıları arasındaki ilişkinin incelenmesi. Kuram ve Uygulamada Ĕ̈itim Yönetimi, 20(2), 151-172.

Demirkart, M. (2016). Illköğretim okulu yöneticilerinin örgütsel sosyalleşme düzeyleri. Yayımlanmamış Yüksek Lisans Tezi, Abant İzzet Baysal Üniversitesi, Bolu.

Doğan, A. E. (2008). İlköğretim okulu yöneticilerinin mesleki etik ilkeleri Kapsamındaki davranışlarının öğretmen algılarına göre değerlendirilmesi. Yayımlanmamış Yüksek Lisans Tezi , Yeditepe Üniversitesi, İstanbul.

Dos Santos, L. M. (2020). The relationship between teachers and school Professional staff's retention and managerial styles. Journal of Education and e-Learning Research, 7(1), 42-48. doi: 10.20448/journal.509.2020.71.42.48

Durnalı, M., Akbaşlı, S., ve Diş, O. (2020). School administrators' communication skills as a predictor of organizational silence. I.e.: Inquiry in Education, 12(1), $1-21$.

Erözyürek, A. (2019). Okul yönetiminin demokratiklik düzeyi ile öğretmenlerin psikolojik iyi oluşları arasındaki ilişki. Yayımlanmamış Yüksek Lisans Tezi, Ondokuz Mayıs Üniversitesi, Samsun.

Ertürk, T. (2017). Türk eğitim sisteminin yapısal sorunları hakkında okul yöneticileri ve öğretmen görüşleri: Şahinbey ilçesi örneği. Yayımlanmamış Yüksek Lisans Tezi, Gaziantep Üniversitesi, Gaziantep. 
Fancera, S. (2016). Principal leadership to improve collective teacher efficacy. NCPEA Education Leadership Review, 17(2). ISSN: 1532-0723

Hilton, A., Hilton, G., Dole, S., ve Goos, M. (2015). School leaders as participants in teachers' professional development: the impact on teachers' and school leaders' professional growth. Australian Journal of Teacher Education, 40(12). http://dx.doi.org/10.14221/ajte.2015v40n12.8

Keçecioğlu, T. (2001). Bir değişimin anatomisi. İstanbul: Alfa Yayıncllı.

Kesimal, A. (2019). Okul yöneticilerinin okul algılar ile ideal okul algıları, öz-yeterlikleri ve felsefi eğilimlerinin incelenmesi. Yayımlanmamış Yüksek Lisans Tezi, Recep Tayyip Erdoğan Üniversitesi, Rize.

Kılınç, A. Ç. (2010). Okul yöneticilerinin etik liderlik davranışları gösterme düzeyleri ile öğretmenlerin yaşadıkları örgütsel güven ve yıldırma arasındaki ilişki. Yayımlanmamış Yüksek Lisans Tezi, Gazi Üniversitesi, Ankara.

Kılınç, A. Ç. (2014). Examining the relationship between teacher leadership and school climate. Educational Sciences: Theory E Practice, 14(5), 1729-1742. doi: 10.12738/estp.2014.5.2159

Kızıldeniz, M. (2017). Başarılı okul müdürlerinin yönetim uygulamalarının değerlendirilmesi. Yayımlanmamış Yüksek Lisans Tezi, Yüzüncüyıl Üniversitesi, Van.

Kurşun, A. T. (2011). Okulların kurumsal imajının okul yöneticilerinin etik liderlik özellikleri ve bazı değişkenler açısından incelenmesi. Yayımlanmamış Yüksek Lisans Tezi, Selçuk Üniversitesi, Konya.

Lee, A. N., ve Nie, Y. (2016). Teachers' perceptions of school leader empowering behaviors on psychological empowerment: a moderated path analysis. New Waves Educational Research \& Development December, 19(2), 36-58.

Meral-Şahin, B. (2016). Eğitimde yönetişim (governance): okul çalışanlarının yönetişim algısı. Yayımlanmamış Yüksek Lisans Tezi , Aksaray Üniversitesi, Aksaray.

Mullen, C. A., \& Browne-Ferrigno, T. (2018). Teacher leadership and teaming: Creativity within schools in China. Research in Educational Administration $\mathcal{E}$ Leadership, 3(2), 231-255. doi: 10.30828/real/2018.2.5

Nyenyembe, F. W., Maslowski, R., Nimrod, B. C., ve Peter, L. (2016). Leadership styles and teachers' job satisfaction in tanzanian public secondary schools. Universal Journal of Educational Research, 4(5), 980-988. doi: 10.13189/ujer.2016.040507

Olsen, A. A., ve Huang, F. L. (2018). Teacher job satisfaction by principal support and teacher cooperation: results from the schools and staffing survey. Education Policy Analysis Archives, 27(11). http://dx.doi.org/10.14507/epaa.27.4174 
Örücü, D. (2014). Öğretmen adaylarının okul, okul yönetimi ve Türk eğitim sistemine yönelik metaforik algıları. Kuram ve Uygulamada Ĕ̆itim Yönetimi, 20(3), 327-358.

Peker, S., İnandı, Y., ve Kılıç, F. (2018). The relationship between leadership styles (autocratic and democratic) of school administrators and the mobbing teachers suffer. European Journal of Contemporary Education, 7(1), 150-164. doi: 10.13187/ejced. 2018.1.150

Sezgin, F. (2006). İlköğretim okulu öğretmenlerinin birey-örgüt değer uyumuna ilişkin algıları. Kuram ve Uygulamada Ĕ̆itim Yönetimi, 48, 557-583.

Şen, E. (2019). Ortaokullarda görev yapan öğretmen ve yöneticilerin öğrenen okul algzları ve bu okullardaki öğrencilerin başarıları. Yayımlanmamış Yüksek Lisans Tezi, Marmara Üniversitesi, İstanbul.

Tsujino, K. (2016). Professional responsibility of school teachers in public education: an analysis of German educational administration from a Japanese perspective. JISTE, 20(1), 32-42.

Wake, D., ve Mills, M. (2018). Edcamp listening to the voices of teachers. Issues in Teacher Education, 27(2), 90-106.

Yavuz-Tabak, B. (2017). Okullarda demokratik okul kültürüne ilişkin görüşlerin belirlenmesi. Yayımlanmamış Doktora Tezi, Gazi Üniversitesi, Ankara.

Yıldırım, R. (2013). Okul yöneticilerinin mentorluk rollerinin okulun akademik başarısı ve bazı değişskenler açısından incelenmesi. Yayımlanmamış Yüksek Lisans Tezi, Necmettin Erbakan Üniversitesi, Konya.

Yılmaz, E. (2006). Okullardaki örgütsel güven düzeyinin okul yöneticilerinin etik liderlik özellikleri ve bazı değişkenler açısından incelenmesi. Yayımlanmamış Doktora tezi, Selçuk Üniversitesi, Konya.

\section{Kaynakça Bilgisi / Citation Information}

Balıkçı, A. (2020). Okul yöneticileri ve öğretmenlere göre okulun anlamlandırılması. OPUS-Uluslararası Toplum Araştırmaları Dergisi, 16(30), 2426-2447. DOI: 10.26466/opus.761574 